\title{
IMPROVEMENT OF ODI AND SF-36 QUESTIONNAIRES SCORE AFTER ONE YEAR OF PLIF OR TLIF
}

\author{
MELHORA NA PONTUAÇÃO DOS QUESTIONÁRIOS ODI E SF-36 APÓS UM ANO DE \\ PLIF OU TLIF \\ MEJORA DE LA PUNTUACIÓN DE LOS CUESTIONARIOS ODI Y SF-36 DESPUÉS DE \\ UN AÑO DE PLIF O TLIF \\ Fabiano Caumo, ${ }^{1,2}$ Carlos Henrique Maçaneiro, ${ }^{1,2,3}$ Ricardo Kiyoshi Miyamoto, ${ }^{1,3}$ Rodrigo Fetter lauffer, ${ }^{1,2,3}$ Ricardo André Acácio dos Santos ${ }^{1,2,3}$ \\ 1. Instituto de Ortopedia e Traumatologia de Santa Catarina - IOT, Joinville, SC, Brazil. \\ 2. Hospital Municipal São José, Joinville, SC, Brazil. \\ 3. Instituto de Ortopedia e Traumatologia de Santa Catarina - IOT, Spine Surgery Service, Joinville, SC, Brazil.
}

\begin{abstract}
Objective: Determine if patients undergoing PLIF or TLIF surgery achieved improvement in the score of ODI and SF-36 questionnaires one year after surgery. Methods: Retrospective, single-center and non-randomized study. Patients submitted to spinal surgery using the PLIF or TLIF technique were included who completed the ODI and SF-36 questionnaires at least at the preoperative visit, and one year after surgery. Patients were divided into two groups, Group 1 (1 surgery level) and Group 2 (> 1 surgery level) and the ODI and SF-36 scores were compared for improvement. Results: The mean age was 47 years, with $52 \%$ of males (13/25) and mean of 5 days of hospital stay. Patients presented a significant improvement of ODI questionnaire $(p<0.001)$ and in all SF-36 domains except in General Health State $(p=0.58)$. In each group, it was observed that patients submitted to more than one level of surgery had greater blood loss and shorter hospital stay; however, the improvement obtained in ODI and SF-36 compared to the one-level surgery group was similar. Conclusions: PLIF and TLIF techniques are effective and lead to improved scores in ODI and SF-36 questionnaires one year after surgery. Patients undergoing two or more levels of instrumentation showed significant and similar improvement in ODI and SF-36. Level of evidence II, Single-Center Retrospective Study.
\end{abstract}

Keywords: Spine/Surgery; Quality of Life; Spinal Fusion.

\section{RESUMO}

Objetivo: Verificar se pacientes submetidos à cirurgia de PLIF ou TLIF obtém melhora nos questionários ODI e SF-36. Métodos: Estudo retrospectivo, de centro único, não randomizado. Foram incluídos pacientes submetidos à cirurgia da coluna vertebral com a utilização da técnica de PLIF ou TLIF, avaliados através dos questionários ODI e SF-36 pelo menos na visita pré-operatória e após um ano de pós-operatório. Os desfechos foram a pontuação no ODI e SF-36. Os pacientes foram, então, subdivididos em dois subgrupos: Grupo 1 (1 nível) e Grupo 2 (>1 nível de cirurgia), que foram comparados em relação a melhora na pontuação dos questionários ODI e SF-36. Resultados: A média de idade foi de 47 anos, com 52\% de pacientes do sexo masculino (13/25) e média de cinco dias de internação. Os pacientes apresentaram melhora significativa nos questionários ODI $(p<0,001)$ e em todos os domínios do SF-36, exceto o Estado Geral de Saúde $(p=0,58)$. Após a subdivisão nos grupos, foi visto que os pacientes submetidos a mais de um nível de cirurgia tiveram maior perda sanguínea e menor período de internação, no entanto, a melhora obtida nos questionários ODI e SF-36, comparados ao grupo com apenas um nível de cirurgia, foi semelhante. Conclusão: As cirurgias de PLIF ou TLIF são eficientes e causam melhora na pontuação dos questionários ODI e SF-36 após 1 ano de cirurgia. Pacientes submetidos a um nível de cirurgia ou a mais de um nível de cirurgia apresentaram melhora significativa e semelhante nos scores de ODI e SF-36. Nível de evidência II; Estudo Retrospectivo, de Centro Único.

Descritores: Coluna Vertebral/Cirurgia; Qualidade de Vida; Fusão Vertebral.

\section{RESUMEN}

Objetivo: Determinar si los pacientes sometidos a cirugía de PLIF O TLIF logaron mejoría en la puntuación de los cuestionarios ODI y SF-36 un año después de la cirugía. Métodos: Estudio retrospectivo, de centro único y no aleatorizado. Se incluyeron pacientes sometidos a cirugía espinal utilizando la técnica PLIF o TLIF que completaron los cuestionarios ODI y SF-36 al menos en la visita preoperatoria y un año después de la cirugía.. Los pacientes se dividieron en dos grupos, el Grupo 1 (1 nivel de cirugía) y el Grupo 2 (> 1 nivel de cirugía) y las puntuaciones de ODI y SF-36 se compararon en cuanto a la mejoría. Resultados: La edad promedio fue de 47 años, con 52\% de hombres (13/25) y una media de 5 días de estancia hospitalaria. Los pacientes presentaron una mejora significativa del cuestionario ODI $(p<0,001)$ y en todos los dominios del SF-36 excepto en el Estado de Salud General ( $p=0,58)$. En cada grupo, se observó que los pacientes sometidos a más de un nivel de cirugía tenían una mayor pérdida de sangre y una estancia hospitalaria más corta; sin embargo, la mejora obtenida en ODI y SF-36 en comparación con el grupo de cirugía de un nivel fue similar. Conclusiones: Las técnicas PLIF y TLIF son efectivas y conducen a mejores puntuaciones en los cuestionarios ODl y SF-36 un año después de la cirugía. Los pacientes sometidos a dos o más niveles de instrumentación mostraron una mejoría significativa y similar en ODI y SF-36. Nivel de evidencia II; Estudio Retrospectivo, de Centro Único.

Descriptores: Columna Vertebral/Cirugía; Calidad de Vida; Fusión Vertebral. 


\section{INTRODUCTION}

With the increase in the life expectancy of the population, the incidence of degenerative lumbar diseases also increases. Because they cause decreased mobility, mechanical pain, and a reduction in the quality of life, they are one of the main causes of disability in the population. ${ }^{1-3}$

In cases of surgical necessity and depending on the diagnosis, specialists may opt for simple direct decompression or direct or indirect decompression with arthrodesis or arthroplasty. ${ }^{1,3,4}$ Recent studies have shown that the placement of interbody cages can increase the fusion rate and reduce the number of operations, since they increase biodynamic stability in the segment, in addition to allowing a greater correction of sagittal alignment. ${ }^{5-7}$

Lumbar interbody fusion can have three main approaches: anterior, lateral, and posterior. ${ }^{8,9}$ Posterior approach techniques that use an interbody cage include transforaminal lumbar interbody fusion (TLIF) and posterior transforaminal interbody fusion (PLIF). 1,10,11

The former entails removal of the upper facet joint of the lower vertebra and the lower facet joint of the upper vertebra of the level to be treated, permitting access to the intervertebral foramen, through which the cage will be placed..$^{1,12,13}$ The PLIF technique involves a laminotomy that allows exposure of the intervertebral space to be treated, promoting access to the disc space by posterior approach and placement of an interbody device. ${ }^{13,14}$ Although they are effective, provide a fusion rate similar to that of other interbody fusion techniques,, 814 involve more extensive dissection of the muscles, longer surgical times, and greater blood loss in relation to other techniques, especially minimally invasive ones, their capacity to improve patient quality of life is often questioned..$^{15}$

For this reason, the objective of our study is to verify whether patients submitted to the PLIF or TLIF technique show improvement in the physical limitation and quality of life ODI and SF-36 questionnaires one year following surgery.

\section{METHODS}

This study is a retrospective, single center analysis of the medical records of patients who underwent PLIF or TLIF surgery between 2015 and 2017 at the Hospital Municipal São José - Joinville, SC. The study was approved by the Institutional Review Board of the Hospital Municipal São José - Joinville, SC, as opinion number 2.654.162. For this study, the IRB approved an exemption from the Informed Consent Form (ICF) requirement.

Patients who had been submitted to the TLIF or PLIF technique and who had filled out the ODI and SF-36 questionnaires at their preoperative and 1-year postoperative visits were included in the study.

The following demographic and intraoperative data were collected: sex, age, levels operated, diagnosis, surgical time, and blood loss. In addition, the ODI and SF-36 questionnaires filled out at the preoperative, 6-week, 3-month, 6-month, and 1-year visits were collected. The results of the questionnaires from each visit were then compared.

The patients were then divided into two groups: Group 1 (patients submitted to 1 level of PLIF or TLIF) and Group 2 (Patients submitted to more than 1 level of PLIF or TLIF). The ODI and SF-36 data (preoperative and 1 year postoperative), as well as blood loss and hospitalization time, were compared between the groups.

The following statistical analyses were used: Student's t-test and ANOVA for numeric values and Chi-square with Pearson's correlation for the nominal data. Values of $p<0.05$ were considered significant.

\section{RESULTS}

A total of 25 cases were included after inclusion criteria assessment. The demographic data of the population are shown in Table 1. The mean age of the patients was 47 years, with $52 \%$ male patients $(12 / 25)$ and an average of $1.76( \pm 0.7)$ levels operated.

All patients presented significant improvement in the Oswestry Disability Index $(p<0.001)$ and SF-36 $(p<0.001)$ scores (Figures 1 and 2$)$.
In addition, the patients were divided into 2 subgroups, 1 level operated (Group 1) and more than 1 level operated (Group 2), to verify whether the number of levels operated has an influence on the improvement in the SF-36 and ODI questionnaires.

After separation into the two groups, there were 14 patients in Group 1 and 11 patients in Group 2. Group 1 had 8 male patients (57\%) and Group 2 had 5 male patients (45\%) ( $>00.05)$, with a

Table 1. Demographic data.

\begin{tabular}{c|c}
\hline Age & $\mathbf{4 7}$ \\
\hline Sex (M/F) & Male (13)/Female (12) \\
\hline Diagnoses & Degenerative Disc Disease (13) \\
\hline & Herniated Disc (12) \\
\hline Levels Operated (levels) & $1.56(+/-0.7)$ \\
\hline Blood Loss $(\mathrm{mL})$ & $402.8(+/-197.64)$ \\
\hline Surgical Time (min) & $122.8(+/-37.8)$ \\
\hline Hospitalization Time (days) & $4.96(+/-0.73)$ \\
\hline
\end{tabular}
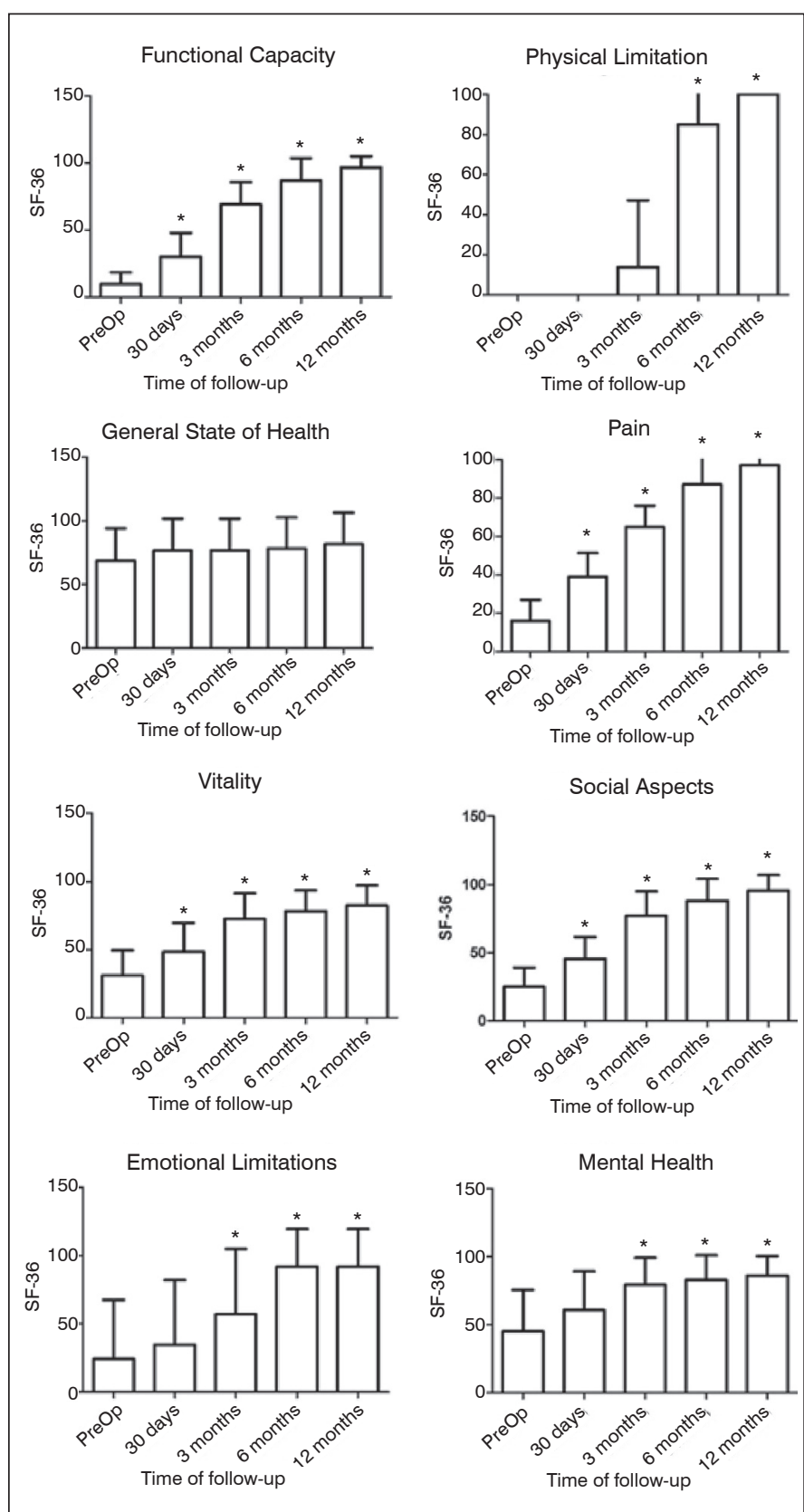

Figure 1 
mean age of 43 and 51 years, respectively $(p=0.01)$. Blood loss and hospitalization time were significantly greater in Group 2 than in Group 1 (Table 2).

The groups had different preoperative ODI scores (Mean: 59 vs. $74, p=0.009$ ) (Figure 3). However, the improvement obtained by both groups 1 year following surgery was significant in relation to the preoperative period and statistically similar to each other $(97 \%$ vs. 98\%, p>0.05) (Figure 4).

As regards the SF-36 questionnaire, the two differed in the following domains: Functional Ability and Pain $(p=0.028$ and $p=0.047)$. (Table 3) The two groups presented significant improvement 1 year after surgical treatment by PLIF or TLIF. (Figure 5) Both groups had improvement percentages without significant difference $(p>0.05$ for all domains).

\section{DISCUSSION}

Nowadays, with the advent of minimally invasive techniques, open surgeries have often come to be seen as antiquated. However, the high cost of materials and high learning curve required for surgeons have made open techniques a much used option in public services. ${ }^{16-18}$

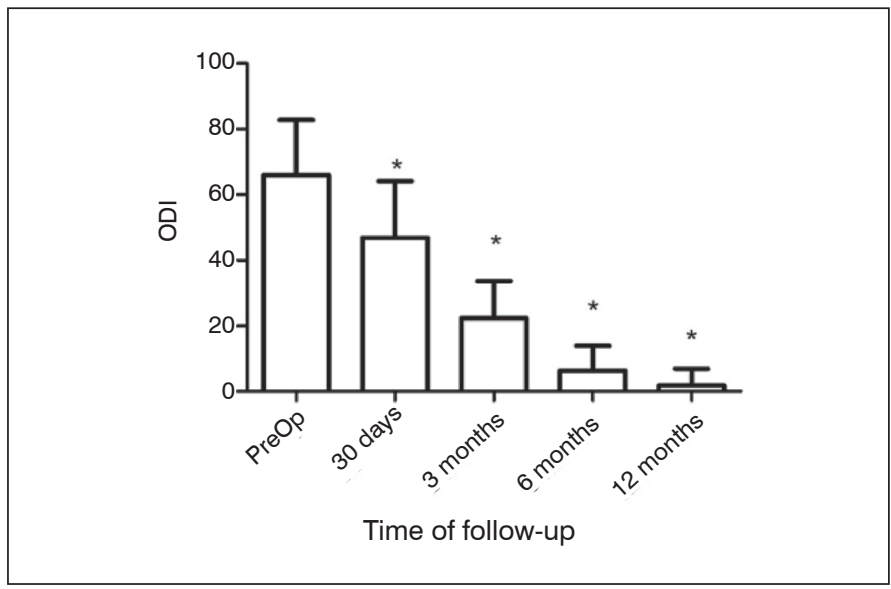

Figure 2.

Table 2. Blood loss and hospitalization time.

\begin{tabular}{c|c|c|c}
\hline & Group 1 (n= 14) & Group 2 (n= 11) & $\mathbf{p}$ \\
\hline Age & 43 & 51 & $0.01^{*}$ \\
\hline Sex (M/F) & Male (8) /Female (6) & Male (5) /Female (6) & 0.33 \\
\hline Diagnoses & Herniated Disc (11) & Herniated Disc (1) & \\
\hline & $\begin{array}{c}\text { Degenerative Disc } \\
\text { Disease (3) }\end{array}$ & $\begin{array}{c}\text { Degenerative Disc } \\
\text { Disease (10) }\end{array}$ & \\
\hline Levels Operated (levels) & $276(+/-104)$ & $563(+/-158)$ & $<0.001$ \\
\hline Blood Loss (mL) & $99(+/-14)$ & $152(+/-35)$ & $<0.001$ \\
\hline Surgical Time (min) & $4.5(+/-0.4)$ & $5.4(+/-0.6)$ & $<0.001$ \\
\hline
\end{tabular}

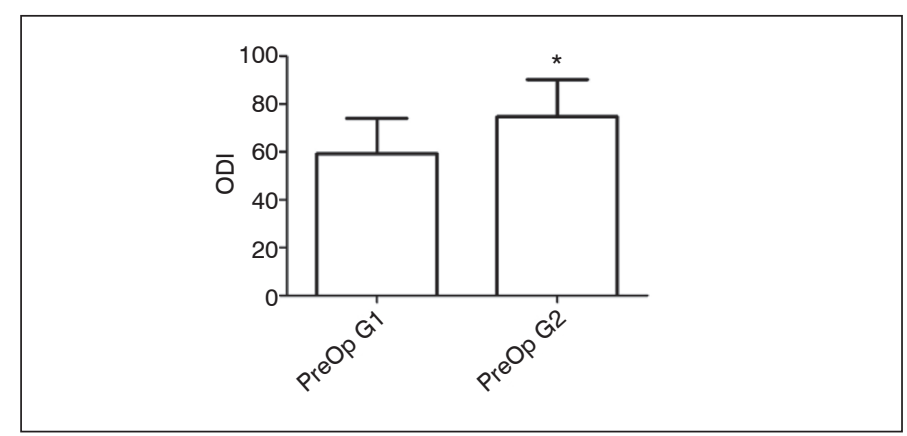

Figure 3.

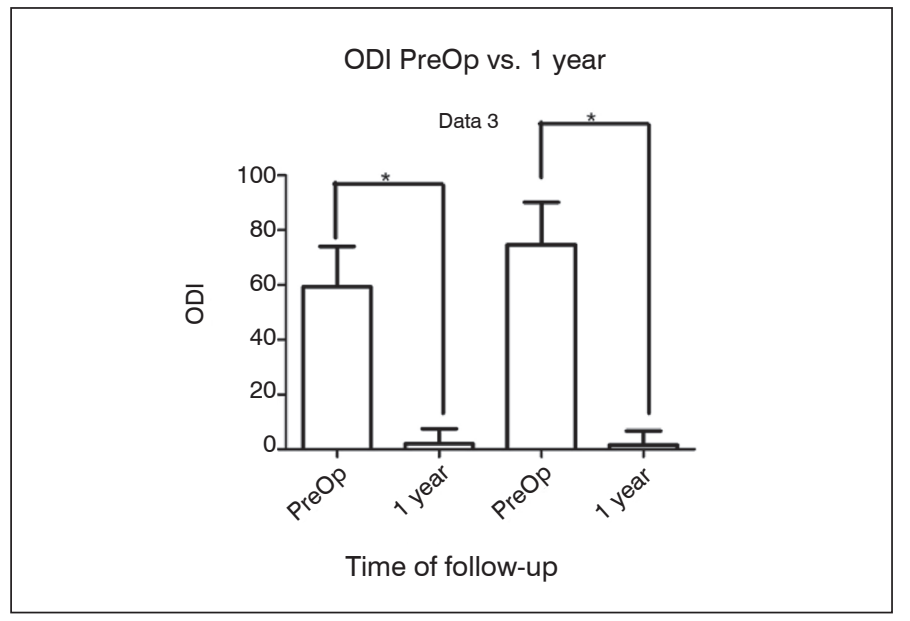

Figure 4.

Table 3.

\begin{tabular}{c|c|c|c}
\hline & $\mathbf{g 1}$ & $\mathbf{g 2}$ & $\mathbf{p}$ \\
\hline Functional Capacity & 12.5 & 5.909091 & 0.028339 \\
\hline Physical Limitation & 0 & 0 & 0 \\
\hline General State of Health & 63.21429 & 59.09091 & 0.359186 \\
\hline Pain & 19.5 & 12.09091 & 0.047296 \\
\hline Vitality & 35 & 25.90909 & 0.114854 \\
\hline Social Aspects & 28.57143 & 20.45455 & 0.076684 \\
\hline Emotional Limitations & 28.57143 & 18.18182 & 0.282653 \\
\hline Mental Health & 54 & 34.54545 & 0.056339 \\
\hline
\end{tabular}

Open posterior and transforaminal lumbar interbody fusion techniques have made the treatment of multiple spinal pathologies possible and have a similar capacity for causing improvement in the ODI and SF-36 indices, ${ }^{19,20}$ as demonstrated in our article, in which, one year following surgery the patients had about $97 \%$ improvement in the ODI and $64 \%$ improvement in all the SF-36 domains.

When the patients were divided into groups, we observed greater blood loss, surgical time, and hospitalization time in the group with more than one operated level. However, one year following surgery, these patients presented improvement similar to that of the group operated at only one level, results similar to those reported by other studies..$^{21,22}$

Although the ODI and SF-36 questionnaires do not guide medical treatment or replace clinical and radiological assessment, they may reveal factors that could interfere with the surgical outcome. ${ }^{23}$ In addition, because they are correlated with the impact that a patient's symptoms have on their quality of life, an improvement in these questionnaires indicates, even if indirectly, that the surgery was efficient in resolving or alleviating their symptoms.

The main limitations of the study are the low number of patients included and the short follow-up time (1 year). In addition, we did not collect complication and reoperation data.

\section{CONCLUSION}

PLIF and TLIF surgeries are efficient and cause improvement of ODI and SF-36 questionnaire scores 1 year following surgery. The patients submitted to the PLIF or TLIF technique showed an improvement of $97 \%$ in the ODI questionnaire score and an average of $64 \%$ in all the domains of the SF-36 1 year after surgery. Both patients who were operated at one level and those operated at more than one level presented significant a similar improvement in their ODI and SF-36 scores.

All authors declare no potential conflict of interest related to this article. 


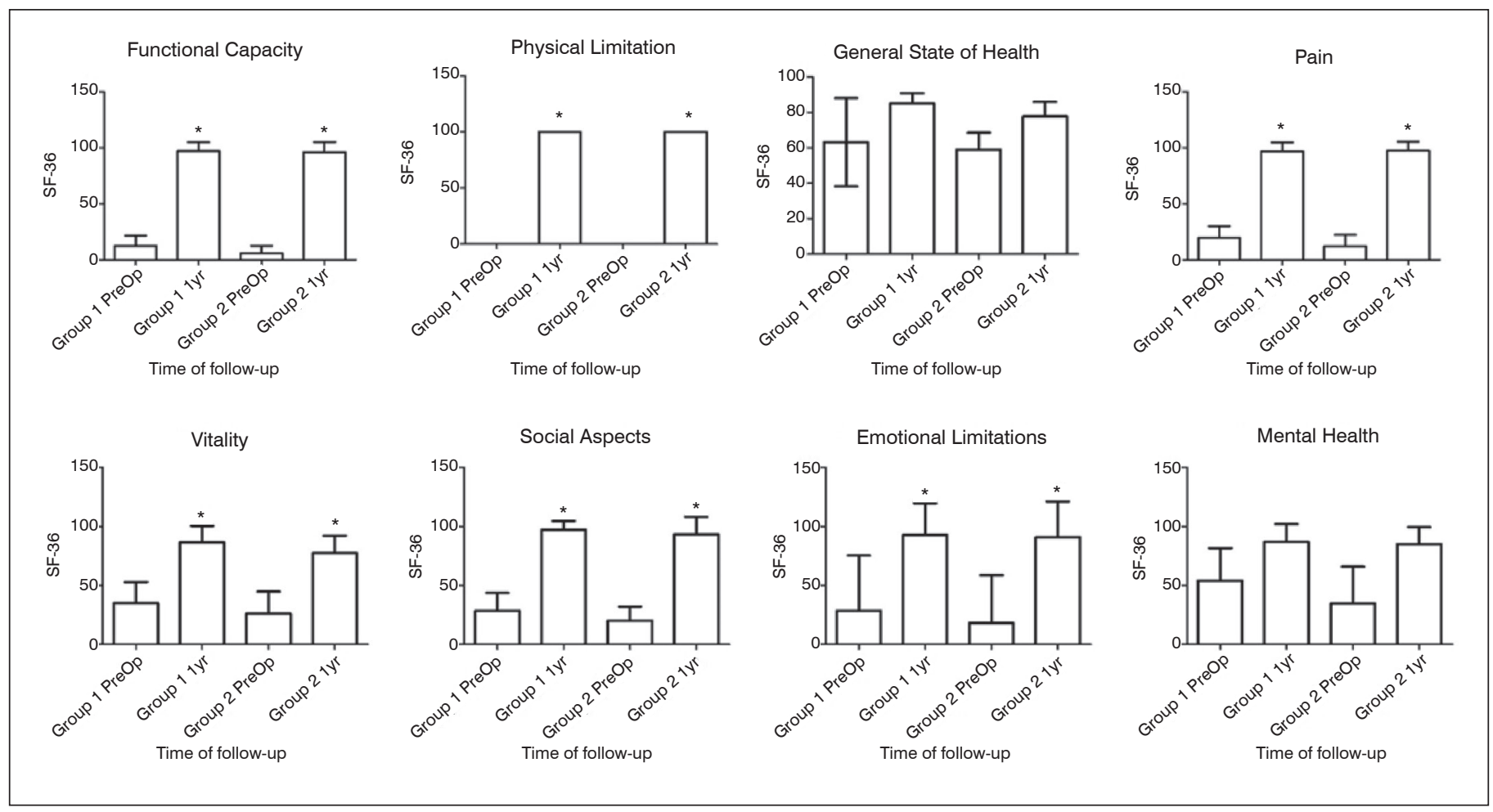

Figure 5.

CONTRIBUTION OF THE AUTHORS: Each author made significant individual contributions to this manuscript. The concept and design were performed by FC (0000-0002-2518-0322)*. Data collection and organization were performed by FC and RAAS (0000-0003-2901-5583)*. Data analysis and interpretation were performed by CHM (0000-0003-4838-3031), RFL (0000-0002-1105-486X)*, RKM (0000-0002-0549-6071)*, RAAS, and FC. The manuscript was written by FC. All authors read, reviewed, and approved the final manuscript. *ORCID (Open Researcher and Contributor ID).

\section{REFERENCES}

1. Mobbs RJ, Phan K, Malham G, Seex K, Rao PJ. Lumbar interbody fusion: techniques, indications and comparison of interbody fusion options including PLIF, TLIF, MI-TLIF, OLIF/ATP, LLIF and ALIF. J Spine Surg. 2015;1(1):2-18.

2. Buser Z, Ortega B, D'Oro A, Pannell W, Cohen JR, Wang J, et al. Spine Degenerative Conditions and Their Treatments: National Trends in the United States of America. Global Spine J. 2018;8(1):57-67.

3. Formica M, Divano S, Cavagnaro L, Basso M, Zanirato A, Formica C, et al. Lumbar total disc arthroplasty: outdated surgery or here to stay procedure? A systematic review of current literature. J Orthop Traumatol. 2017;18(3):197-215.

4. Omidi-Kashani F, Hasankhani EG, Ashjazadeh A. Lumbar Spinal Stenosis: Who Should Be Fused? An Updated Review. Asian Spine J. 2014;8(4):521-30.

5. Bydon M, Macki M, Abt NB, Witham TF, Wolinsky JP, Gokaslan ZL, et al. The costeffectiveness of interbody fusions versus posterolateral fusions in 137 patients with lumbar spondylolisthesis. Spine J. 2015;15(3):492-8.

6. Macki M, Bydon M, Weingart R, Sciubba D, Wolinsky JP, Gokaslan ZL, et al. Posterolateral fusion with interbody for lumbar spondylolisthesis is associated with less repeat surgery than posterolateral fusion alone. Clin Neurol Neurosurg. 2015;138:117-23.

7. Campbell RC, Mobbs RJ, Lu VM, Xu J, Rao PJ, Phan K. Posterolateral Fusion Versus Interbody Fusion for Degenerative Spondylolisthesis: Systematic Review and MetaAnalysis. Global Spine J. 2017;7(5):482-90.

8. Teng I, Han J, Phan K, Mobbs R. A meta-analysis comparing ALIF, PLIF, TLIF and LLIF. J Clin Neurosci. 2017:44:11-7.

9. Derman PB, Albert TJ. Interbody Fusion Techniques in the Surgical Management of Degenerative Lumbar Spondylolisthesis. Curr Rev Musculoskelet Med. 2017:10(4):530-8.

10. Fujimori T, Le H, Schairer WW, Berven SH, Qamirani E, Hu SS. Does Transforaminal Lumbar Interbody Fusion Have Advantages over Posterolateral Lumbar Fusion for Degenerative Spondylolisthesis? Global Spine J. 2015;5(2):102-9.

11. Cole CD, McCall TD, Schmidt MH, Dailey AT. Comparison of low back fusion techniques: transforaminal lumbar interbody fusion (TLIF) or posterior lumbar interbody fusion (PLIF) approaches. Curr Rev Musculoskelet Med. 2009;2(2):118-26.

12. Figueiredo N, Martins JWG, Arruda AA, Serra AR, Figueiredo MAA, Diniz RC, et al. TLIF: transforaminal lumbar interbody fusion. Arq Neuro-Psiquiatr. 2004;62(3B):815-20.

13. Kobayashi K, Ando K, Kato F, Kanemura T, Sato K, Hachiya Y, et al. Reoperation within 2 years after lumbar interbody fusion: a multicenter study. Eur Spine J. 2018;27(8):1972-80.

14. Lan T, Hu SY, Zhang YT, Zheng YC, Zhang R, Shen Z, et al. Comparison between posterior lumbar interbody fusion and transforaminal lumbar interbody fusion for the treatment of lumbar degenerative diseases: a systematic review and meta-analysis. World Neurosurg. 2018;112:86-93.

15. Menezes CM, Falcon RS, Ferreira Jr MA, Alencar J. Clinical and radiological evaluation of open transforaminal lumbar interbody fusion versus minimally invasive. Coluna/Columna. 2009:8(3):297-302.

16. Epstein NE. Learning curves for minimally invasive spine surgeries: Are they worth it? Surg Neurol Int. 2017;8:61.

17. Sclafani JA, Kim CW. Complications Associated With the Initial Learning Curve of Minimally Invasive Spine Surgery: A Systematic Review. Clin Orthop Relat Res. 2014;472(6):1711-7.

18. Nandyala SV, Fineberg SJ, Pelton M, Singh K. Minimally invasive transforaminal lumbar interbody fusion: one surgeon's learning curve. Spine J. 2014;14(8):1460-5.

19. Glassman S, Gornet MF, Branch C. Polly D, Peloza J, Schwender JD, et al. MOS short form 36 and Oswestry Disability Index outcomes in lumbar fusion: a multicenter experience. Spine J. 2006;6(1):21-6

20. Chen X, Xu L, Qiu Y, Chen Z, Zhou Q, Li S, et al. Higher Improvement in PatientReported Outcomes Can Be Achieved After Transforaminal Lumbar Interbody Fusion for Clinical and Radiographic Degenerative Spondylolisthesis Classification Type D Degenerative Lumbar Spondylolisthesis. World Neurosurg. 2018;114:e293-300.

21. Lee WC, Park JY, Kim KH, Kuh SU, Chin DK, Kim KS, et al. Minimally Invasive Transforaminal Lumbar Interbody Fusion in Multilevel: Comparison with Conventional Transforaminal Interbody Fusion. World Neurosurg. 2016;85:236-43.

22. Bechara AHS, Zuiani GR, Risso Neto MI, Cavali PTM, Veiga IG, Pasqualini W, et al. Evolution of Oswestry 2.0 questionnaire and the physical component (PCS) of SF-36 during the first postoperative year of lumbar spine fusion in degenerative diseases. Coluna/Columna. 2013;12(2):128-32

23. Falavigna A, Teles AR, Braga GL de, Barazzetti DO, Lazzaretti L, Tregnago AC. Instruments of clinical and functional evaluation in spine surgery. Coluna/Columna. 2011;10(1):62-7. 